\title{
Entrepreneurial Marketing, Corporate Reputation, Corporate Creativity and Competitive Advantage: A Research Framework and Proposition
}

\author{
${ }^{1}$ Silas Gontur, ${ }^{2}$ Linus Jonathan Vem, ${ }^{2}$ Meshach Gomam Goyit, and ${ }^{1}$ Makrop Davireng \\ ${ }^{1}$ Department of Business Education, Federal College of Education Pankshin \\ ${ }^{2}$ Department of Business Administration, University of Jos \\ sgontur@gmail.com, linusvem@unijos.edu.ng,
}

\begin{abstract}
This study explored the consequences of entrepreneurial marketing by creating empirical evidence grounded in dynamic capability and image theory. The study proposed a direct as well as an indirect relationship between entrepreneurial marketing and competitive advantage, recognizing corporate creativity as the boundary condition under which entrepreneurial marketing influences competitive advantage suggesting that corporate creativity is a moderator in the entrepreneurial marketing model. The study explained the theoretical and practical contributions of the model in our understanding of entrepreneurial marketing practices and the role of corporate reputation. Corporate creativity was also discussed especially from the perspective of entrepreneurial firms.
\end{abstract}

Keywords: Entrepreneurial Marketing, Corporate Reputation, Corporate Creativity, Competitive Advantage.

\section{How to Cite:}

Gontur, S., Vem, L. J., Goyit, M. G., and Davireng, M. (2022). Entrepreneurial marketing, corporate reputation, corporate creativity and competitive advantage: A research framework and proposition. International Journal of Business, Management and Economics, 3(1). 52 80. DOI: https://doi.org/10.47747/ijbme.v3i1.352

\section{Introduction}

There has been a convergence of opinion by both academics and practitioners on the disparity in the marketing strategy employed by small firms and larger firms. Expanding on this idea, it is safe to say that the kind of marketing behaviour observed in an individual entrepreneurial firm deviates from what is common in main stream marketing (Sole, 2013; Gilmore, 2010). Some authors have worked on these differences (Gaddefors \& Anderson, 2008; Sole, 2013) and concluded that the process of entrepreneurial marketing (EM) differs from the regular approaches to marketing (Collinson \& Shaw, 2001). Entrepreneurial marketing can be perceived as a novel model that incorporates important features of marketing and entrepreneurship into a comprehensive concept where marketing becomes a process used by enterprises as well as acting entrepreneurially (Ferreira, Ferguson \& Pitt, 2019; Collinson, et 
al 2001). Some entrepreneurial marketing strategies have been identified as; guerrilla marketing, ambush marketing, buzz marketing and viral marketing (Rollins \& Anitsal, 2014; Sadiku- Dushi, Dana, Ramadani, 2019). These types are judged very helpful for entrepreneurial firms because they are low cost and innovative forms of practicing marketing (Sadiku- Dushi et al, 2019).

Entrepreneurial firms operate in an environment characterized by high risk, and decreased ability to forecast (Olannye \& Eromafaru, 2016). The operational landscape of this environment is often controlled by rapid changes, complex decision, and customers' high expectations, leaving the entrepreneurs with limited options (Hills Hultman \& Miles, 2008). In addition, the current happenings present firms and entrepreneurs with limited option following the devastating effect of the global economic melt-down and recently the COVID 19 pandemic which ravaged the global economy, with businesses losing trillions of dollars. These resulted in the creation of a new normal which is reshaping marketing activities globally with customers taking the lead (Miles, \& Jones 2020). In the new normal, Gross Domestic Product (GDP) was projected to decline by $2.1 \%$ and $2.5 \%$ in developed and developing countries respectively with income increasing by $1.9 \%$ (Malizewska, Muttoo \& Mensubrugghe, 2020). These events have brought- forth new ways of tackling marketing activities and other consequences within. In the contemporary business environment, with growing dynamics, instability and rivalry, entrepreneurs and managers have to unlearn traditional marketing principles and replace them with innovative opinions and procedures, such as entrepreneurial marketing (Hills, Hultman, Kraus, \& Schulte, 2010)

The concept of entrepreneurial marketing has been adjudged by scholars and practitioners as a key source of superior firm performance (Njeru \& Kibera, 2019; Abdullahi, Mohammed, Syed \& Ghazali, 2017). Though EM has been found to enhance business success regardless of size, there appears to be a consensus on its higher impact on small businesses (Jones \& Rowley, 2011; Morris, et al, 2002). Hill, Hultman and Miles (2008) and Eggers, Niemand, Kraus and Breier, (2020) underscored the importance of examining marketing efforts used in small firms as opposed to predominantly researched large firms with much resources. In view of this, researchers have examined the antecedents and consequences of EM among SMEs (Fiore, Niehm, Hurst, Son \& Sadachar, 2013). A cursory survey of existing literature reveals that entrepreneurial marketing has a positive impact on firms' performance (Becherer, Helms, \& McDonald, 2012; Hacioglu, Eren, Eren, \& Celikkan, 2012; Fiore et al, 2013; Morrish \& Deacon, 2012; Mugambi \& Karugu, 2017; Sadiku- Dushi, Dana \& Radamani, 2019). Evidence also indicated that entrepreneurial marketing practices have consequences for product/service innovation, market research and service quality which enable firms to gain competitive advantage (Jayawarna, Jones, Lam \& Phua 2014).

Flowing from the preceding findings, this study proposes a model of entrepreneurial marketing focusing on the consequences in ensuring competitive advantage. We found the dynamic capability view (Teece, Pisano \& Shuen, 1997) underpinning the study while the image theory (Beach \& Mitchell, 1998) played supporting role. This study departs from the current debate by exploring the consequences of entrepreneurial marketing, thus presenting a parsimonious model on its impact on competitive advantage. Peterson (2020) had expressed concern that EM researchers have devoted scant attention to the link with external environmental conditions. He was not surprised that important explanations for EM have 
remained underdeveloped as debate on EM as a strategic response to environmental change and turbulence is lost (Peterson, 2020). Thus, we theorize that corporate reputation, corporate creativity and competitive advantage interplay as consequences of entrepreneurial marketing.

A study of this nature is important in expanding the literature on entrepreneurial marketing in business firm especially in the context of small firms. The theoretical expositions would set an agenda on entrepreneurial marketing in the context of entrepreneurial firms, providing propositional arguments that would give a lucid exploration of the consequences of entrepreneurial marketing. Another significance of the study is the understanding of the role of corporate reputation and corporate creativity in the link between entrepreneurial marketing and competitive advantage. While corporate reputation serves as the mechanism, corporate creativity forms the boundary condition under which the relationship between the predictor and the outcomes becomes plausible (Baron \& Kenny, 1986). Lastly, the conceptualized model is applicable to small firms that adopt entrepreneurial marketing practices rather than large business corporations, providing a more slightly different approach of the consequences of entrepreneurial marketing with other outcomes.

\section{Literature Review}

\subsection{Theoretical Foundation}

Underpinning this study is the dynamic capabilities view (Teece, Pisano \& Shuen 1997). Dynamic capabilities is the organizational and strategic routines by which the firm achieves new resource configurations as markets emerge, collide, split, evolve and die in changing business environment (Teece, et al, 1997, p. 509). It is linked to firms' performance in that it changes the firm's bundle of resources, operations, routines and competencies (Kanyabi \& Dew, 2012). In other words, dynamic capabilities reflect a path-breaking perspective for entrepreneurial marketing (Sole, 2014). In the context of this study entrepreneurial marketing, corporate reputation and corporate creativity are considered as intangible resources of a firm that enable it manage market information, company image and also deliver superior value for its customers (Rindova, Williams, \& Petkova 2010; Kamasak, 2017).

In addition, image theory supports the underpinning theory in explaining the role of corporate reputation in the model. The theory was developed by Lee Roy Beach and Terence Mitchell in 1970. It has two complementary tracks which are for personnel and organizational decisions (Beach, \& Mitchell, 1998). Images are representation of the decision maker's perception of some aspects of the organization such as organizational culture (belief, morals, ethics, values, norms) and organizational prestige. The primary goal of corporate firm is the maintenance of positive image (Massey, 2011) in relating with its key stakeholders. A firm's communication strategy with stakeholders is to encode a desirable message (Massey, 2015), to create a positive perception about the corporation (Van der, Marweis \& Puth, 2016). When effective corporate image with the stakeholders is created, chances for success and competitiveness are enhanced (Mason, 2014; \& Massey, 2011).

Within the framework of this theory, corporate image is one of the intangible assets that create an important strategic competitive advantage over its rivals because it is a resource that helps firms to differentiate it from others because it is rare, difficult to imitate, buy other organizations or firm without substitute (Barney, 1991). In addition, the theory places great emphasis on creating a positive image showing the level of organization, commitment to 
quality, excellence and relationships with its various constituents ranging from employees, customers, government and other stakeholders. If this image of the firm is properly managed, it will protect the organization against competition from new competitors or current competitors offering new products and services (Okocha, Otika \& Osuagwu, 2019).

In a sum, dynamic capabilities enable firms to reconfigure and recreate their responses to internal and external changes relating to their image, quality of goods and services offered and network. When these are done right through its EM strategies, it sparks positive corporate reputation due to favourable decisions made by customers and organizations towards the organization. In addition, dynamic capabilities are expressed in terms of creativity as such high corporate creativity which is an indicator of high dynamic capabilities strengthens EM activities while low creativity weakens the predictive strength of EM on CA.

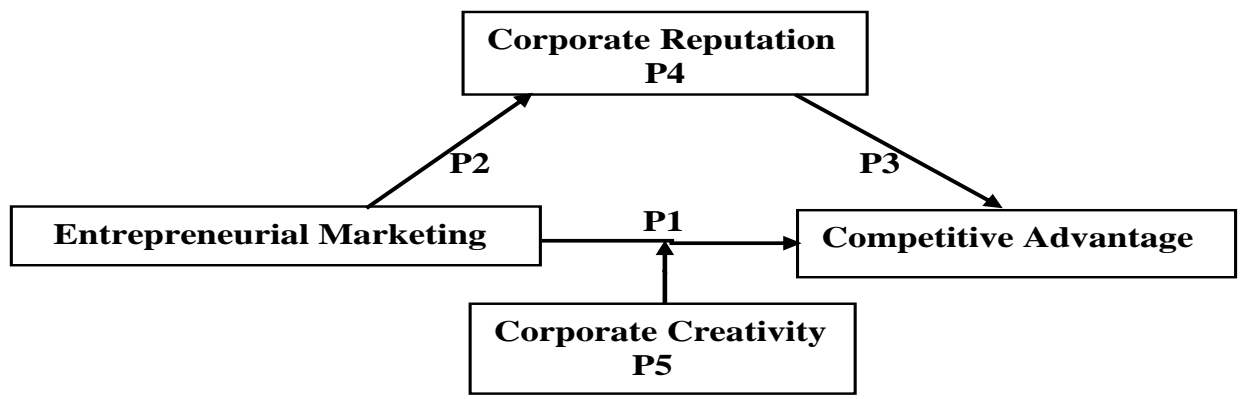

Figure 1 Research Framework

\subsection{Entrepreneurial Marketing (EM)}

Entrepreneurial marketing has come into view as an important field in both academic study and marketing practice over the past decades (Gilmore, McAuley, Gallagher \& Carson, 2013; Ferreira, Ferguson \& Pitt, 2019). The numerous similarities between entrepreneurship and marketing resulted in the emergence of this construct (Gilmore et al, 2013; Sole, 2013; Hill \& Hultman, 2011; Morris, Scindehutte \& La Forge, 2002). Earlier authors have argued that both entrepreneurship and marketing focus on the importance of identifying opportunities and operating in a constantly changing environment (Omura, Calantone \& Schmidt, 1993; Ferreira et al, 2019). Omura et al, (1993) also identified further areas of clear overlap in marketing and entrepreneurial attributes (Bjerke \& Hultman, 2002; Collinson \& Shaw, 2001). The term has been used in various ways and often somewhat loosely used (Morris et al, 2002:4). Sole (2013) observed that its intriguing confusion arises because each item can be interpreted differently but are related.

Scholars have different conceptualizations for EM. For instance, Morris et al, (2002, p.5) define EM as the "proactive identification and exploitation of opportunities for acquiring and retaining profitable customers through innovative approaches to risk management, resources leveraging and value creation." Whalen, Uslay, Pascal and Gilmore $(2016$, p. 3) define it as a combination of innovative, proactive, and risk-taking activities that create, communicate, and 
deliver value to and by customers, entrepreneurs, marketers, their partners, and society at large.

However, EM is a term that is difficult to grasp (Kurgun, Bagiran, Ozren, \& Maral, 2011). We can see this in Bjerke and Hultman (2002), who think EM is the marketing of small firms growing through entrepreneurship. The idea of restricting EM to small firms was recently challenged in the study conducted by Eggers, Niemand, Kraus and Breier, (2020); Kraus, Harms, and Fink (2010) noting that EM is an approach that can be used by firms of all sizes, ages and industry affiliations. Though the practice has been common especially in small firms, most entrepreneurially market- oriented firms find it useful (Collinson \& Shaw, 2001). According to Hills and Hultman (2011), EM is a product of three elements: entrepreneurial analysis of information, conclusion, and marketing behaviour. Eggers, Niemand, Kraus and Breier, (2020), on the other hand, departed from this conceptualization and proved that EM is the function of three factors namely; 1) change-driving, 2) boot-strapping, and 3) risk-taking.

Change-driving refers to firm's behaviour that challenges and goes beyond the status-quo through pro-activeness, innovativeness and market driving. Bootstrapping, on the other hand, involves resource leverage and customer orientation, it is an aspect of EM that establishes the firm with cost efficient, customer-focused marketing programs. The interplay of changedriving and bootstrapping, what Eggers et al. (2020:7) describe as "radical, proactive, marketdriving behaviours and a more conservative, resource-leveraging customer focus" makes EM a sought-after approach in all firms and at all stages. Risk-taking as a factor shows its inherency within the two factors. Though going beyond customer needs and wants as stipulated in EM may involve some level of risk, imagine the opposite which involves focusing on customers and cost-conscious behaviour which might involve firms missing out on growth opportunities or even be led into unprofitable directions (Eggers et al., 2020). How riskier would that be in a competitive business environment?

Basically, entrepreneurial marketing practices in the firm have been discussed under different concepts such as entrepreneurial orientation and market orientation (Al- Mamum, Mohiuddin, Fazal, \& Ahmad, 2017), entrepreneurial marketing orientation (Jones \& Rowley, 2011), entrepreneurial marketing process (Miles, Lewis, Hall Morrish, Gilmore \& Kasouf, 2016). In the context of our study, entrepreneurial marketing is seen as an opportunity driven way of thoughts and actions concerning marketing behaviours (Morris et al, 2002) as a result understanding and responding to market styles, market positioning and customers' needs (Fiore, Niehm, Hurst, Son \& Sadauchar, 2013).

\subsection{Competitive Advantage}

In recent years, the concept of competitive advantage has been a hot issue among management guilds, with many controversies raised. This perhaps is owed to the subjective interpretation of what it means for a firm to have advantage over another in absolute terms. Therefore, providing a precise definition of competitive advantage is a difficult task, seeing that it is defined in many different ways. For example, Porter $(1985$, p.2) defined it "as the comparative positional superiority in the market place that leads a firm to outperform its rivals." Sigalas - Pekka, Economou, and Georgopolous, (2013, p.322) described it as the degree to which a firm exploits its opportunities, neutralizes threats and reduces cost. In addition, Rothaermel (2013, p. 45) defined it as 'the way a firm formulates and implements a 
strategy that leads to superior performance relative to other competitors in the same industry. In the context of this study, we adopt the definition of Rothaermel (2013), because it involves the firms adopting effective strategies that would help perform better than other firms. To achieve competitive advantage, a firm must pay attention to its external position as well as internal capabilities. Different scholars have identified different perspectives to competitive advantage which have been used by researchers to measure this concept. Table one summarises the different perspectives presented by some scholars.

Table 1: Perspectives to Competitive Advantage

\begin{tabular}{ll}
\hline Authors & Conceptualization \\
\hline $\begin{array}{l}\text { Porter (1985) } \\
\text { Miles \& Darroch (2006) }\end{array}$ & $\begin{array}{l}\text { Cost advantage and differentiation } \\
\text { Organizational resources, ability, Market } \\
\text { superiority, pursue of opportunity. } \\
\text { Cost, quality delivery, dependability, product } \\
\text { innovation, and time to market }\end{array}$ \\
\hline Li \& Zhou (2010) & $\begin{array}{l}\text { Institution advantage, cost advantage and } \\
\text { differentiation }\end{array}$ \\
Bratic (2011) & $\begin{array}{l}\text { Price, quality delivery, product innovation } \\
\text { and time to market }\end{array}$ \\
Peng, Shoeder, \& Shah (2011) & $\begin{array}{l}\text { Cost priority, delivery priority, flexibility } \\
\text { priority and Innovation } \\
\text { Image quality, Differentiation, contact, and } \\
\text { price } \\
\text { Cost, flexibility, delivery and quality } \\
\text { Mihalic \& Buhalic (2013) }\end{array}$ \\
Diab (2014) & $\begin{array}{l}\text { Flexibility, creativity, cost and } \\
\text { differentiation }\end{array}$ \\
Al-Najjar (2016) & \multicolumn{1}{c}{} \\
\hline
\end{tabular}

\subsection{Entrepreneurial Marketing and Competitive Advantage}

Research has explored the consequences of EM which triggered interest among academics and practitioners (Fiore, et al, 2013). This is in view of its drive to create access and successfully exploit attractive economic opportunities by leveraging on the resources of the organization (Morrish, Miles \& Deacon, 2010) resulting in driving the desire, needs and motives of the entrepreneurs. In other words, innovation and creativity in EM can trigger the creation of new products to satisfy the needs of customers and owners of businesses.

Empirical evidences (Altinay, Madanoglu, Vita, Arasil, \& Ekinci, 2016) have identified entrepreneurial, marketing has been studied with different outcomes such as sales and market growth (performance (Sadiku- Dushi, Dana \& Ramadani, 2019), corporate reputation (Orlando \& Alexander, 2018), firm success (Becherer, et al, 2012), electronic customer relationship management (Harrigan, Ramsey, \& Ibbotson, 2012), hybrid entrepreneurship (Ferreira, Ferguson \& Pitt, 2019), coo petition (Crick 2017), commitment (Jansson, Nilsson, Modig \& Hed- Hall, 2015), consumer engagement (Al- Mamum, Mohiuddin, Fazal \& Ahmed, 2017) as consequences of EM. Buccieri, Javalgi, and Gross (2021). Mahrous, 
Genedy, and Kalling (2020), Zeebaree, and Siron (2017) established that entrepreneurial marketing dimensions are positively related to competitive advantage and differentiation and low-cost strategy

Consistent with dynamic capabilities theory which focuses on how firms integrate, build and reconfigure their specific internal and external competence into a form that matches the turbulence in their business environment (Teece, Pisano, \& Shuen, 1997), it is expected that firms with greater dynamic capabilities will perform better than those with less capability. Juxtaposing this with EM, which involves the interplay of change-driving, bootstrapping, and risk-taking, which Eggers et al. (2020:7) describe as "radical, proactive, market-driving behaviours and a more conservative, resource-leveraging customer focus", a firm that possesses EM capabilities is expected to function effectively in a turbulent business environment, hence out-performing those with less EM capabilities. We therefore propose that:

Proposition 1: The experience of entrepreneurial marketing by a firm to greater extent will lead to competitive advantage of the firm

\subsection{Entrepreneurial Marketing and Corporate Reputation}

Corporate reputation refers to "a perceptual representation of a company's past actions and future prospects that describe the organization's overall appeal to all its key constituents when compared to other leading rivals" (Fombrun, 1996, p. 72). It is understood from different perspectives such as economic, strategic, marketing, organizational studies and marketing. Economic view refers to what the firm is, what it does, what it represents, its capability to exist and influence on economic agents (Fombrum et al, 2000; Carreras Alloza \& Carreras, 2013). Strategic view is the source of differentiation which is difficult to imitate, because of its intangible nature and its potential for value creations, it is complex and cannot be easily replicated by competitors (Fombrun, 1996, and Waeraas, 2015). Marketing view focuses on brand equity such that positive relationship between client and the company is a function of the firm's brand name (Carreras et al, 2013), where reputation is seen as perceptual asset with the power to attract loyal customers. Organizational view is the firm's identity and culture that shapes business practices. It provides the basis for internal stakeholders, for the achievement of organizational objectives (Carreras, et al, 2013). In the context of this study, corporate reputation is seen from the marketing perspective, where EM is expected to create new brands and focus on ensuring equity and customer loyalty.

Empirical evidences confirm that EM associates with different behavioural outcomes, though dearth of empirical evidences exists in the relationship between entrepreneurial marketing and corporate reputation as intended in this study. In any case, Orlando and Alexandra (2018) and Sadiku- Dushi et al, (2019) inferred that entrepreneurial marketing has a direct link with performance outcomes such as reputation. Similarly, Grissemann, Plank, and BrunnerSperdin (2013) concluded that customer orientation and innovativeness are some of the dimensions of EM that are positively associated with corporate reputation. In addition, environmental marketing has been found to be a significant predictor of corporate reputation (Mulyganegara, 2011; Williams, Buttle \& Biggerman, 2012, Di Souza, Taghian, \& SullivanMort, 2013). Likewise, Ozkan, Suer, Keser and Kocakoc, (2019) found that that corporate 
image and corporate reputation can be used as a common marketing benchmark to measure a firm's performance.

We argue using the Image theory, that images are representation of the decision maker's perception of some aspects of the organization such as organizational capabilities and organizational prestige. An organization's dynamic capability perceived or communicated through EM activities is expected to influence the internal and external stakeholders' worldview regarding reputation which could be positive or negative. Therefore, firms that are entrepreneurial and dynamic in their capabilities are expected to create good reputation for their companies and will respond favourably by producing products and services that will meet the needs of their customers positively in the environment it operates. In line with the forgone, we therefore propose that;

Proposition 2: The experience of entrepreneurship marketing to greater extent will influence corporate reputation of entrepreneurial firms.

\subsection{Role of Corporate Reputation}

The literature on the consequences of corporate reputation is rich and diverse. Its richness is founded on the claim that corporate reputation is linked to positive organizational outcomes such as word of mouth (Manohari, Mittal, \& Maroush, 2020; Williams, Buttle, \& Biggerman, 2012), customer loyalty (Bartikouski, Walsh, \& Bealty, 2011; Akpi, Vem \& Eshue, 2020) corporate social responsibility (Park, 2019) branding (Weng \& Chen, 2017), commitment (Jansson, Nilsson, Modig \& Hed, 2015), firm success (Bercherer etal 2012) as consequences of entrepreneurial marketing. Empirically, numbers of studies have established positive relationship between corporate reputation and competitive advantage. For instance, Miotto, Del- Castillo-Fato and Blanco-Gonzalez, (2020) advanced that legitimacy and firm reputation are critical intangible assets in order to ensure or sustain competitive advantage and therefore guarantee firm survival and growth. In addition,. Bruna and Nicolò, (2020) and Sheehan, and Stabell (2010) found that firm reputation impacts the firm's competitive position and concludes that reputation is a key driver of competitive advantage.

On the flipped-side, organizational factors have been found to influence corporate reputation. For instance, Aksak, Ferguson, \& Duman, (2016) in a review discovered corporate social responsibility as a strong predictor of corporate reputation. Others which include, corporate branding, (Abralt \& Kleyn, 2012), environmentally motivated actions (D'Souza, Taghian, \& Sullivan-Mort, 2013), stakeholders' reputation (Ji, Li, North, \& Liu, 2017), green supply chain (Quintana-García, Benavides-Chicón, \& Marchante-Lara, 2020) are all found to influence organization's reputation. Similarly, Ozkan, Suer, Kaiser and Kocako (2019) revealed that corporate reputation and image mediate the relationship between service quality and customer satisfaction on customer loyalty. In addition, Saeidi, Sofian, Saeidi, Saeidi, and Saeidi, (2015) and Pham, and Tran (2020) established that reputation mediate the relationship between corporate social responsibility (CSR) and firm performance, likewise in, Arikan, Kantur, Maiden, and Telci (2016) advanced that corporate reputation fully mediates the relationship between CSR and multiple stakeholders outcomes such as organizational commitment, purchase intention and intention to seek employment. From the empirical evidence, the choice of corporate reputation as a mediator of this study is appropriate. 
Consistent with the empirical evidences and the theoretical lenses of dynamic capability and image theory we contend that corporate reputation being an image created as a result of a firm's dynamic capability in EM influences firm's competitive advantage. Therefore, we make the following propositions:

Proposition 3: The experience of corporate reputation of entrepreneurial firms to a greater extent will influence competitive advantage amongst firms

Proposition 4: The experience of corporate reputation by entrepreneurial firm mediates the relationship between entrepreneurial marketing and competitive advantage

\subsection{Role of Corporate Creativity (CC)}

In addition to corporate reputation which serves as mechanism that explains the relationship between EM and CA, we found corporate creativity useful in determining the boundary condition under which the relationship is plausible in the proposed framework (Baron \& Kenny 1986). Creativity is considered an important factor for building a successful enterprise in a turbulent and competitive business environment as characterise in the $21^{\text {st }}$ century. It enables organizations to exploit and respond to market opportunities, leading to competitive advantage (Gontur, Makrop \& Gadi, 2016).

The concept of creativity has majorly been studied at individual level. Recently, creativity debate has been extended to the organizational level (Ghosh 2015; Park, Cho, Park, \& Shin, 2019; Darvishmotevali, Altinay, \& Köseoglu, 2020). According to their argument, Creative organizations design, create structures, which coordinate creative activities and create conducive environment for internal and external collaborations among members. Creativity according to Woodman, Sawyer, and Griffin, (1993:293) is "the creation of a valuable, useful new product, service, idea, procedure, or process by individuals working together in a complex social system." Organizational creativity is seen as the development of special features of the products, individuals, and through processes, or an enabling environment which stimulates the flourishing of creative activities (Koch, Wenzel, Senf, \& Maibier, 2018). It has widely been reckoned with as antecedent to competitive advantage (Anderson, Potočnik, \& Zhou, 2014; De Vasconcellos, Garrido, \& Parente, 2019).

In corporate world, creativity has been associated with positive firm's outcomes such as increased general effectiveness, increased market share, which drives new product development and harnessed competitive advantage of a firm (Dixit, Singh, Dhir \& Dhir, 2021; Annan, \& Adeola, 2017; Csikszentmihelyi \& Sawyer, 2014). In addition, Zameer, Wang \& Yasmeen, (2019), identified that green creativity directly has a positive role in reinforcing green competitive advantage. In addition, corporate creativity predicts level of organizational survival (Tripathi \& Ghosh, 2020, return on investment and customer base (Ogbari, Isiavwe, Ajagbe \& Oke, 2015), knowledge management (Dixt et al, 2021). Kathiravan, Bhagavathan, Palanisamy and Rajaseker, (2019) that knowledge spill-over and entrepreneurial creativity has a greater impact on firm's competitiveness in the market place.

Buttressing this argument using dynamic capability view emphasizes how firm's ability to integrate, build and configure internal and external capabilities to address rapidly changing environment that is characterized by new technologies, ideas, and innovation would influence 
the competitiveness of the firm. Building on this premise, it is expected that corporate creativity may unlock the potentials of firm and will further strengthen entrepreneurial marketing link with competitive advantage. In accordance with the existing literature on organizational creativity and theoretical evidences, we propose that, corporate creativity interacts with EM in determining firm's level of competitive advantage.

Proposition 5: CC moderates the relationship between EM and CA such that; high CC Strengthens the impact of EM, while low CC weakens the impact on competitive advantage.

\section{Research Method}

A comprehensive check of literature allows the researchers to review the works of other researchers in the field of study and to stay away from repeating what other scholars had done. To re-examine the literature, we searched for studies on entrepreneurial marketing on competitive advantage of SMEs, mediating role of corporate reputation and moderating role of corporate creativity in Nigeria and other countries. The review of the literature involved researching articles to gain in depth knowledge of entrepreneurial marketing practices in SMEs, and the dynamic capability theory and image theory that we used as the conceptual framework of the study.

The studies chosen are the work of researchers in Nigeria and other parts of the world. The literature review includes 97 peer-reviewed journals, nine books, one conference paper, and one working paper. We reviewed a total number of 108 papers with $90 \%$ of the articles published in or after 2015. The databases that we used include the Emerald Management Journal, ABI-INFORM Complete Pro Quest, Science Direct, Directory of Open Access Journal, World Bank Publication, Institutional Based Research, and Google Scholar. A total of thirty five (35) empirical articles were identified consisting of thirty three (33) studies published in journals targeting those who explored the consequences of entrepreneurial marketing in SMEs. The database search included different combination of words such as entrepreneurial marketing, corporate reputation, corporate creativity, competitive advantage, firm performance, market orientation, entrepreneurial orientation and small and medium enterprises (SMEs), dynamic capability theory, and image theory. This was based on availability and accessibility of articles.

This section captures the study methodology and in line with the study objectives, a detailed literature review was adopted which was achieved in phases. A search was carried out using phrases such as marketing and entrepreneurial interface, entrepreneurial orientation, entrepreneurial firms, market orientation, entrepreneurial marketing orientation, entrepreneurial marketing, corporate reputation, corporate creativity, competitive advantage, entrepreneurial marketing and competitive advantage, entrepreneurial marketing and corporate reputation, corporate reputation and competitive advantage. This was based on availability and accessibility of articles. 
Table 2: Studies Related to Entrepreneurial Marketing, Firm Reputation and Corporate Creativity

\begin{tabular}{|c|c|c|c|c|c|}
\hline $\begin{array}{l}\text { S\N } \\
\text { O }\end{array}$ & $\begin{array}{l}\text { Paper Titles \& } \\
\text { Authors }\end{array}$ & Source & $\begin{array}{l}\text { Variable and their } \\
\text { role }\end{array}$ & $\begin{array}{l}\text { Sample size } \text { and } \\
\text { Tools }\end{array}$ & Results \\
\hline 1 & $\begin{array}{l}\text { Innovation and } \\
\text { differential of } \\
\text { Emerging market } \\
\text { international new } \\
\text { ventures: the role } \\
\text { of entrepreneurial } \\
\text { marketing. } \\
\text { Buccieri et al, } \\
\text { (2021). }\end{array}$ & $\begin{array}{l}\text { Journal } \\
\text { of } \\
\text { Strategic } \\
\text { Marketin } \\
\text { g (Taylor } \\
\text { and } \\
\text { Francis) }\end{array}$ & $\begin{array}{l}\text { Innovation and } \\
\text { differentiation } \\
\text { independent and } \\
\text { dependent variable) } \\
\text { Entrepreneurial } \\
\text { Marketing } \\
\text { (mediator) }\end{array}$ & $\begin{array}{l}\text { A sample of - } \\
\text { innovative firms } \\
\text { from India and data } \\
\text { were empirical } \\
\text { tested }\end{array}$ & $\begin{array}{l}\text { The result indicates } \\
\text { that entrepreneurial } \\
\text { marketing shapes } \\
\text { differentiation } \\
\text { strategy (cost) that } \\
\text { is competitive } \\
\text { advantage }\end{array}$ \\
\hline 2 & $\begin{array}{l}\text { Antecedents of } \\
\text { strategic thinking } \\
\text { and its impact on } \\
\text { competitive } \\
\text { advantage by } \\
\text { Dixit, Singh, } \\
\text { Dhir\& Dhir } \\
(2021)\end{array}$ & Emerald & $\begin{array}{l}\text { Strategic thinking } \\
\text { and competitive } \\
\text { advantage }\end{array}$ & $\begin{array}{lr}220 \text { professionals } \\
\text { from various } \\
\text { industries in India. } \\
\text { Quantitative using } \\
\text { Partial least square } \\
\text { structural equation } \\
\text { modelling } \\
\text { methodology using } \\
\text { Smart } & \text { PLS } \\
\text { software. } & \end{array}$ & $\begin{array}{l}\text { Creativity is } \\
\text { established with } \\
\text { strategic thinking, as } \\
\text { well as } \\
\text { competitive } \\
\text { advantage. Also, } \\
\text { The study finds a } \\
\text { significant } \\
\text { relationship between } \\
\text { strategic thinking } \\
\text { and competitive } \\
\text { advantage }\end{array}$ \\
\hline 3 & $\begin{array}{l}\text { Effects of } \\
\text { entrepreneurial } \\
\text { marketing on } \\
\text { new ventures' } \\
\text { exploitative and } \\
\text { exploratory } \\
\text { innovation: The } \\
\text { moderating role } \\
\text { of competitive } \\
\text { intensity and firm } \\
\text { size by } \\
\text { Bachmann, } \\
\text { Ohlies and } \\
\text { Flatten (2021) }\end{array}$ & Elsevier & $\begin{array}{l}\text { Entrepreneurial } \\
\text { marketing, new } \\
\text { venture exploitative } \\
\text { and exploratory } \\
\text { innovation. } \\
\text { Competitive } \\
\text { intensity and firm } \\
\text { size. }\end{array}$ & $\begin{array}{l}146 \text { German new } \\
\text { ventures. } \\
\text { Questionnaire was } \\
\text { use to collect data }\end{array}$ & $\begin{array}{l}\text { Under conditions of } \\
\text { high competitive } \\
\text { intensity, the effects } \\
\text { of EM on } \\
\text { exploratory } \\
\text { innovation } \\
\text { strengthen, while } \\
\text { low levels of } \\
\text { competitive } \\
\text { intensity do not } \\
\text { affect } \\
\text { relationship between } \\
\text { EM and exploratory } \\
\text { innovation. Our } \\
\text { results also show } \\
\text { that for larger firms, } \\
\text { the positive effects } \\
\text { of EM on } \\
\text { exploitative } \\
\text { innovation are } \\
\text { weaker, while for } \\
\text { smaller firms, those } \\
\text { effects are stronger. }\end{array}$ \\
\hline
\end{tabular}




\begin{tabular}{|c|c|c|c|c|c|}
\hline 4 & $\begin{array}{l}\text { The link between } \\
\text { environmental } \\
\text { uncertainty, } \\
\text { organizational } \\
\text { agility, and } \\
\text { organizational } \\
\text { creativity in the } \\
\text { hotel industry by } \\
\text { Darvishmotevali } \\
\text { Altinay\&Köseogl } \\
\text { u (2020) }\end{array}$ & Elsevier & $\begin{array}{l}\text { Environmental } \\
\text { uncertainty, } \\
\text { organisational } \\
\text { agility and } \\
\text { organisational } \\
\text { creativity }\end{array}$ & $\begin{array}{l}\text { The sample size is } \\
174 \text { managers of } \\
\text { hostels. Hypotheses } \\
\text { were analyzed using } \\
\text { AMOS }\end{array}$ & $\begin{array}{l}\text { The findings show } \\
\text { that organizational } \\
\text { agility moderates } \\
\text { the negative impacts } \\
\text { of competitive and } \\
\text { technological } \\
\text { uncertainty on } \\
\text { organizational } \\
\text { creativity }\end{array}$ \\
\hline 5 & $\begin{array}{l}\text { The impact of } \\
\text { characteristics of } \\
\text { intra- } \\
\text { organizational } \\
\text { environment on } \\
\text { entrepreneurial } \\
\text { marketing } \\
\text { intensity and } \\
\text { performance in } \\
\text { Egypt Mahrous et } \\
\text { al (2020) }\end{array}$ & $\begin{array}{l}\text { Journal } \\
\text { of } \\
\text { Entrepre } \\
\text { neurship } \\
\text { in } \\
\text { Emergin } \\
\mathrm{g} \\
\text { Economi } \\
\text { es } \\
\text { (Emerald } \\
\text { ) }\end{array}$ & $\begin{array}{l}\text { Entrepreneurial } \\
\text { Marketing } \\
\text { (Independent } \\
\text { Variable), } \\
\text { performance and } \\
\text { Competitive } \\
\text { advantage } \\
\text { (Dependent } \\
\text { variables) }\end{array}$ & A conceptual paper & $\begin{array}{l}\text { It was found that } \\
\text { entrepreneurial } \\
\text { marketing is } \\
\text { positively related to } \\
\text { organizational } \\
\text { performance and } \\
\text { competitive } \\
\text { advantage }\end{array}$ \\
\hline & $\begin{array}{l}\text { Corporate } \\
\text { reputation and } \\
\text { social } \\
\text { sustainability In } \\
\text { the early stages } \\
\text { of start-ups: A } \\
\text { theoretical model } \\
\text { to match } \\
\text { stakeholders } \\
\text { 'expectations } \\
\text { through corporate } \\
\text { social } \\
\text { commitment by } \\
\text { Bruna, and } \\
\text { Nicolò. (2020) }\end{array}$ & $\begin{array}{l}\text { Financial } \\
\text { Letter } \\
\text { Elsevier }\end{array}$ & $\begin{array}{l}\text { Corporate } \\
\text { reputation, } \\
\text { social sustainability } \\
\text { and corporate } \\
\text { social } \\
\text { commitment }\end{array}$ & $\begin{array}{l}\text { Theoretical paper } \\
\text { with mathematic } \\
\text { modelling }\end{array}$ & $\begin{array}{l}\text { Corporate } \\
\text { Reputation, helps in } \\
\text { the mitigation of the } \\
\text { young- } \\
\text { companies' } \\
\text { vulnerability }\end{array}$ \\
\hline 6 & 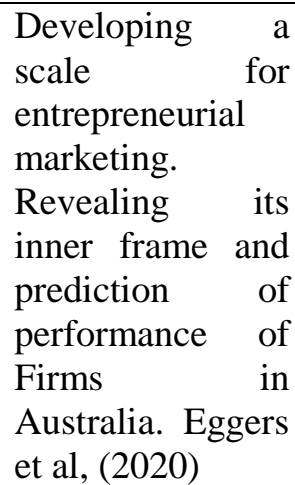 & $\begin{array}{l}\text { Journal } \\
\text { of } \\
\text { Business } \\
\text { Research } \\
\text { (Elsevier } \\
\text { ) }\end{array}$ & $\begin{array}{l}\text { Entrepreneurial } \\
\text { Marketing } \\
\text { (Independent } \\
\text { Variable) and Firm } \\
\text { Performance } \\
\text { (Dependent } \\
\text { Variable) }\end{array}$ & $\begin{array}{l}\text { A sample of } 1155 \\
\text { Australian firms, } \\
\text { online questionnaire. } \\
\text { Random sampling } \\
\text { technique was used. } \\
\text { The tool for analysis } \\
\text { was Partial Least } \\
\text { Square (PLS) }\end{array}$ & 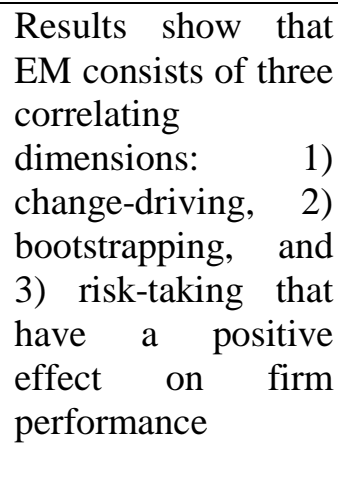 \\
\hline 7 & Corporate Social & Journal & Corporate & Data collected from & revealed \\
\hline
\end{tabular}




\begin{tabular}{|c|c|c|c|c|c|}
\hline & $\begin{array}{l}\text { Responsibility } \\
\text { Disclosure and } \\
\text { Firm } \\
\text { Performance. The } \\
\text { mediating role of } \\
\text { corporate } \\
\text { reputation and } \\
\text { moderating role } \\
\text { of Chief } \\
\text { Executive Officer } \\
\text { (CEO). Pham \& } \\
\text { Tran, (2020) }\end{array}$ & $\begin{array}{l}\text { of } \\
\text { Business } \\
\text { Research } \\
\text { (Science } \\
\text { Direct) }\end{array}$ & $\begin{array}{l}\text { Responsibility } \\
\text { Disclosure } \\
\text { (Independent } \\
\text { Variable), Firm } \\
\text { performance } \\
\text { (Dependent } \\
\text { variable), corporate } \\
\text { reputation } \\
\text { (Mediating } \\
\text { variable), and CEO } \\
\text { (moderator) }\end{array}$ & $\begin{array}{l}833 \text { fortune world } \\
\text { most admired firms } \\
\text { in } 31 \text { Countries from } \\
2005 \text { TO } 2011\end{array}$ & $\begin{array}{l}\text { corporate reputation } \\
\text { mediates the } \\
\text { relationship between } \\
\text { CSR and firm } \\
\text { performance. }\end{array}$ \\
\hline 8 & $\begin{array}{l}\text { Effect of } \\
\text { Entrepreneurial } \\
\text { marketing and } \\
\text { performance of } \\
\text { SMEs. Sadiku- } \\
\text { Dushi. (2019) }\end{array}$ & $\begin{array}{l}\text { Journal } \\
\text { of } \\
\text { Business } \\
\text { Research } \\
\text { (Elsevier } \\
\text { ) }\end{array}$ & $\begin{array}{l}\text { Entrepreneurial } \\
\text { Marketing } \\
\text { (Independent } \\
\text { Variable) and } \\
\text { SMEs Performance } \\
\text { (Dependent } \\
\text { Variable) }\end{array}$ & $\begin{array}{lr}\text { Questionnaire } & \text { was } \\
\text { used to collect } & \text { data } \\
\text { through drop and } \\
\text { pick from } & 250 \\
\text { respondents. } & \end{array}$ & $\begin{array}{l}\text { The study revealed } \\
\text { that EM dimensions } \\
\text { of opportunity } \\
\text { recognition, } \\
\text { resource leveraging, } \\
\text { value creation, } \\
\text { customer intensity, } \\
\text { and innovation } \\
\text { focus are positively } \\
\text { related } \\
\text { performance } \\
\text { outcomes } \\
\text { reputation, } \\
\text { efficiency profit and } \\
\text { growth }\end{array}$ \\
\hline 9 & $\begin{array}{l}\text { Effect of Service } \\
\text { quality and } \\
\text { customer } \\
\text { satisfaction and } \\
\text { loyalty The } \\
\text { mediating role of } \\
\text { corporate } \\
\text { reputation. } \\
\begin{array}{l}\text { Ozkan, Suer, } \\
\text { Keser, \& Kocak. } \\
\text { (2019) }\end{array}\end{array}$ & $\begin{array}{l}\text { Journal } \\
\text { of Bank } \\
\text { Marketin } \\
\mathrm{g} \\
\text { (Emerald } \\
\text { ) }\end{array}$ & $\begin{array}{l}\text { Service Quality, } \\
\text { (Independent), } \\
\text { Customer } \\
\text { Satisfaction and } \\
\text { Loyalty and } \\
\text { Corporate } \\
\text { reputation } \\
\text { (Mediator) }\end{array}$ & $\begin{array}{ll}\text { Survey design } & \text { was } \\
\text { used and SEM was } \\
\text { used for } & \text { data } \\
\text { analysis with } & 300 \\
\text { respondent } & \\
\text { measured on } 5 & \text { point } \\
\text { Likert scale } & \end{array}$ & $\begin{array}{l}\text { Discovered that } \\
\text { corporate reputation } \\
\text { mediates the } \\
\text { relationship between } \\
\text { service quality and } \\
\text { customer } \\
\text { satisfaction on } \\
\text { customer loyalty }\end{array}$ \\
\hline 10 & $\begin{array}{l}\text { Corporate social } \\
\text { responsibility as } \\
\text { a determinant in } \\
\text { the air line } \\
\text { industry. Park } \\
(2019)\end{array}$ & $\begin{array}{l}\text { Journal } \\
\text { of } \\
\text { Retailing } \\
\text { and } \\
\text { Consume } \\
\mathrm{r} \\
\text { Services } \\
\text { (Elsevier } \\
\text { ) }\end{array}$ & $\begin{array}{l}\text { Corporate } \\
\text { Reputation } \\
\text { (Independent } \\
\text { variable) and } \\
\text { customer loyalty }\end{array}$ & $\begin{array}{l}\text { The study used } \\
\text { convenient sampling } \\
\text { technique which has } \\
\text { a sample size of } \\
2100 \text { respondents. }\end{array}$ & $\begin{array}{l}\text { Found out that } \\
\text { corporate reputation } \\
\text { has a significant } \\
\text { impact on consumer } \\
\text { attitude and } \\
\text { customer loyalty }\end{array}$ \\
\hline 11 & $\begin{array}{l}\text { Reinforcing } \\
\text { green competitive }\end{array}$ & Elsevier & $\begin{array}{l}\text { Green competitive } \\
\text { advantage, green }\end{array}$ & $\begin{array}{lr}320 & \text { managers and } \\
320 & \text { customers. }\end{array}$ & $\begin{array}{l}\text { creativity } \\
\text { have a }\end{array}$ \\
\hline
\end{tabular}




\begin{tabular}{|c|c|c|c|c|c|}
\hline & $\begin{array}{l}\text { advantage } \\
\text { through green } \\
\text { production, } \\
\text { creativity and } \\
\text { green } \\
\text { image. brand } \\
\text { Implication for } \\
\text { cleaner } \\
\text { production in } \\
\text { China by Zameer, } \\
\text { Wang \& } \\
\text { Yasmeen (2019) }\end{array}$ & & $\begin{array}{l}\text { production, } \\
\text { creativity and green } \\
\text { brand image }\end{array}$ & $\begin{array}{l}\text { Convenience based } \\
\text { structural equation } \\
\text { modelling (CBSEM) } \\
\text { and AMO }\end{array}$ & $\begin{array}{l}\text { positive role in } \\
\text { reinforcing green } \\
\text { competitive } \\
\text { advantage }\end{array}$ \\
\hline 12 & $\begin{array}{l}\text { Application of } \\
\text { Whiteheadian } \\
\text { Creativity to } \\
\text { Corporate } \\
\text { Creativity: A } \\
\text { Five Cs } \\
\text { Creativity Model } \\
\text { by Park et al } \\
\text { (2019) }\end{array}$ & $\begin{array}{l}\text { Research } \\
\text { gate }\end{array}$ & $\begin{array}{l}\text { Creativity and } \\
\text { corporate creativity }\end{array}$ & Conceptual Review & $\begin{array}{l}\text { A five Cs creativity } \\
\text { model, deriving } 3 \mathrm{Cs} \\
\text { from creative } \\
\text { imagination and } 2 \mathrm{Cs} \\
\text { from the creative } \\
\text { structure. }\end{array}$ \\
\hline 13 & $\begin{array}{l}\text { Influence of } \\
\text { Entrepreneurial } \\
\text { Creativity on } \\
\text { Competitive } \\
\text { Advantage in } \\
\text { Automobile } \\
\text { Engineering and } \\
\text { Technologies } \\
\text { Industries by } \\
\text { Kathiravan et al } \\
(2019)\end{array}$ & $\begin{array}{l}\text { Research } \\
\text { gate }\end{array}$ & $\begin{array}{l}\text { Entrepreneurial } \\
\text { creativity and } \\
\text { competitive } \\
\text { advantage }\end{array}$ & $\begin{array}{l}160 \text { firms, the data } \\
\text { was analysed using } \\
\text { PLS }\end{array}$ & $\begin{array}{ll}\text { There is } & \text { the } \\
\text { influence } & \text { of } \\
\text { entrepreneurial } & \\
\text { creativity } & \text { on } \\
\text { competitive } & \\
\text { advantage } & \text { in } \\
\text { automobile } & \\
\text { industries } & \end{array}$ \\
\hline 14 & $\begin{array}{l}\text { The effect of } \\
\text { service quality } \\
\text { and customer } \\
\text { satisfaction on } \\
\text { customer loyalty } \\
\text { The mediation of } \\
\text { perceived value } \\
\text { of services, } \\
\text { corporate image, } \\
\text { and corporate } \\
\text { reputation by } \\
\text { Ozkan, Suer, } \\
\text { Keser \& Kocakoc } \\
\text { (2019) }\end{array}$ & Emerald & $\begin{array}{l}\text { service quality and } \\
\text { customer } \\
\text { satisfaction on } \\
\text { customer loyalty: } \\
\text { The mediation of } \\
\text { perceived value of } \\
\text { services, corporate } \\
\text { image, } \\
\text { corporate } \\
\text { reputation }\end{array}$ & $\begin{array}{l}163 \text { males } 121 \\
\text { females. } \\
\text { Quantitative } \\
\text { using SEM analysis }\end{array}$ & $\begin{array}{l}\text { The findings of the } \\
\text { survey indicate that } \\
\text { corporate image and } \\
\text { corporate reputation } \\
\text { can be used as a } \\
\text { common marketing } \\
\text { benchmark to } \\
\text { measure a bank's } \\
\text { performance }\end{array}$ \\
\hline 15 & $\begin{array}{l}\text { Innovation and } \\
\text { Creativity in } \\
\text { Organizations: }\end{array}$ & $\begin{array}{l}\text { Research } \\
\text { gate }\end{array}$ & $\begin{array}{lr}\text { Innovation } & \text { and } \\
\text { creativity } & \text { in } \\
\text { organisations } & \end{array}$ & A Conceptual paper & $\begin{array}{ll}\text { Creativity } & \text { and } \\
\text { innovation in } & \text { any } \\
\text { organization } & \text { are }\end{array}$ \\
\hline
\end{tabular}


Vol. 3 No. 1, February 2022

\begin{tabular}{|c|c|c|c|c|c|}
\hline & $\begin{array}{l}\text { State-of-the- } \\
\text { Science Review, } \\
\text { Prospective } \\
\text { Commentary, and } \\
\text { Guiding } \\
\text { Framework by } \\
\text { Anderson, } \\
\text { Potočnik and } \\
\text { Zhou (2019) }\end{array}$ & & & & $\begin{array}{l}\text { vital to its } \\
\text { successful } \\
\text { performance }\end{array}$ \\
\hline 16 & $\begin{array}{l}\text { Organizational } \\
\text { Creativity as an } \\
\text { Attributional } \\
\text { Process: The } \\
\text { Case of Haute } \\
\text { Cuisine by Kock, } \\
\text { et al (2018) }\end{array}$ & Sage & $\begin{array}{l}\text { Organisational } \\
\text { creativity and } \\
\text { attribution process }\end{array}$ & $\begin{array}{l}\text { Interviews with } \\
\text { Chefs, } \\
\text { critics/experts } \\
\text { Haute-cuisine } \\
\text { restaurant Rutz in } \\
\text { Berlin }\end{array}$ & $\begin{array}{l}\text { The study } \\
\text { demonstrates how } \\
\text { the sequential } \\
\text { performance of } \\
\text { these entre-relating } \\
\text { activities is } \\
\text { consequential for } \\
\text { the gradual } \\
\text { transition of external } \\
\text { evaluations of an } \\
\text { organization's } \\
\text { outcomes, from } \\
\text { being considered } \\
\text { 'different' to 'one of } \\
\text { a kind', and thus the } \\
\text { increasing } \\
\text { attribution } \\
\text { organizational of } \\
\text { creativity over time. }\end{array}$ \\
\hline 17 & $\begin{array}{l}\text { Organizational } \\
\text { creativity as a } \\
\text { crucial resource } \\
\text { for building } \\
\text { international } \\
\text { business } \\
\text { competence by } \\
\text { Vasconcellosa, } \\
\text { Garrido\&Parente } \\
\text { (2018) }\end{array}$ & Elsevier & Organisational & $\begin{array}{ll}\text { creativity } & \text { and } \\
\text { international } & \\
\text { business } & \\
\text { competence. The } \\
\text { data } \\
\text { analysed using OLS } \\
\text { regression method }\end{array}$ & $\begin{array}{l}\text { The results partially } \\
\text { support the } \\
\text { hypothesis that } \\
\text { organizational } \\
\text { creativity is a } \\
\text { building block for } \\
\text { IBC }\end{array}$ \\
\hline 18 & $\begin{array}{l}\text { The impact of } \\
\text { entrepreneurial } \\
\text { marketing on } \\
\text { innovative } \\
\text { marketing } \\
\text { performance in } \\
\text { small- and } \\
\text { medium-sized } \\
\text { companies by }\end{array}$ & $\begin{array}{l}\text { Taylor } \\
\text { and } \\
\text { Francis }\end{array}$ & $\begin{array}{l}\text { Entrepreneurial } \\
\text { marketing, } \\
\text { innovative } \\
\text { marketing } \\
\text { performance }\end{array}$ & $\begin{array}{l}\text { The sample size of } \\
\text { this study is } 195 \\
\text { small firms in - } \\
\text { Structural equation } \\
\text { modeling (SEM) } \\
\text { was used to analysed } \\
\text { the data }\end{array}$ & $\begin{array}{l}\text { The results show } \\
\text { that value creation } \\
\text { that includes } \\
\text { creating value for } \\
\text { customers through } \\
\text { the products and } \\
\text { services, and } \\
\text { marketing activities } \\
\text { and technology has }\end{array}$ \\
\hline
\end{tabular}




\begin{tabular}{|c|c|c|c|c|c|}
\hline & $\begin{array}{l}\text { Rezvani and } \\
\text { Fathollahzadeh } \\
\text { (2018) }\end{array}$ & & & & $\begin{array}{l}\text { the greatest impact } \\
\text { on innovative } \\
\text { performance }\end{array}$ \\
\hline 19 & $\begin{array}{l}\text { The impact of } \\
\text { entrepreneurial } \\
\text { orientation on } \\
\text { competitive } \\
\text { advantage } \\
\text { moderated by } \\
\text { Financing } \\
\text { support in SMEs } \\
\text { in Iraq. Zeebaree } \\
\text { and Siron et al. } \\
\text { (2017) }\end{array}$ & $\begin{array}{l}\text { Internatio } \\
\text { nal } \\
\text { Review } \\
\text { of } \\
\text { Manage } \\
\text { ment and } \\
\text { Marketin } \\
\text { g } \\
\text { (DOAJ) }\end{array}$ & $\begin{array}{l}\text { Entrepreneurial } \\
\text { Orientation } \\
\text { (Independent } \\
\text { Variable), } \\
\text { Competitive } \\
\text { Advantage } \\
\text { (dependent } \\
\text { variable), } \\
\text { Financing Support } \\
\text { (moderator) }\end{array}$ & $\begin{array}{l}\text { The study adopted a } \\
\text { quantitative } \\
\text { approach using } \\
\text { survey instrument. A } \\
\text { sample size of } 680 \\
\text { small firms in Iraq. } \\
\text { Structural Equation } \\
\text { Model (SEM) was } \\
\text { used to examine the } \\
\text { relationship among } \\
\text { the variables. }\end{array}$ & $\begin{array}{l}\text { It shows that } \\
\text { entrepreneurial } \\
\text { orientation } \\
\text { dimensions of } \\
\text { innovation and pro- } \\
\text { activeness } \\
\text { significantly } \\
\text { influence } \\
\text { competitive } \\
\text { advantage. }\end{array}$ \\
\hline 20 & $\begin{array}{l}\text { The role of } \\
\text { market } \\
\text { orientation, } \\
\text { creativity and } \\
\text { innovation in } \\
\text { creating } \\
\text { competitive } \\
\text { advantages and } \\
\text { creative industry } \\
\text { performance by } \\
\text { Sutapa, Mulyana } \\
\text { and Wasitowati } \\
\text { (2017) }\end{array}$ & $\begin{array}{l}\text { Institutio } \\
\text { nal based }\end{array}$ & $\begin{array}{l}\text { Market orientation, } \\
\text { creativity, } \\
\text { innovation, } \\
\text { competitive } \\
\text { advantage and } \\
\text { creative industry } \\
\text { performance }\end{array}$ & $\begin{array}{l}130 \text { owners of } \\
\text { creative industries } \\
\text { quantitative using } \\
\text { PLS }\end{array}$ & $\begin{array}{l}\text { Creativity has no } \\
\text { significant effect on } \\
\text { innovation }\end{array}$ \\
\hline 21 & 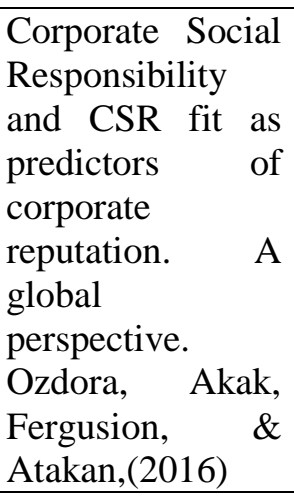 & $\begin{array}{l}\text { Public } \\
\text { Relations } \\
\text { Review } \\
\text { (Elsevier } \\
\text { ) }\end{array}$ & $\begin{array}{l}\text { Corporate Social } \\
\text { Responsibility, } \\
\text { CSR fit } \\
\text { (Independent } \\
\text { variable) and } \\
\text { Corporate } \\
\text { Reputation } \\
\text { (mediating } \\
\text { variable) }\end{array}$ & $\begin{array}{l}\text { A conceptual } \\
\text { analysis was carried } \\
\text { out }\end{array}$ & $\begin{array}{l}\text { The result of the } \\
\text { conceptual analysis } \\
\text { revealed most } \\
\text { studies on CSR and } \\
\text { reputation functions } \\
\text { on practical } \\
\text { implications without } \\
\text { contributing to the } \\
\text { theoretical } \\
\text { framework }\end{array}$ \\
\hline 22 & $\begin{array}{l}\text { Assessing the } \\
\text { relationship } \\
\text { between } \\
\text { entrepreneurial } \\
\text { orientation, } \\
\text { reputational } \\
\text { resources and } \\
\text { absorptive } \\
\text { capacity: a }\end{array}$ & $\begin{array}{l}\text { Institutio } \\
\text { nal based }\end{array}$ & $\begin{array}{l}\text { Entrepreneurial } \\
\text { orientation, } \\
\text { reputational } \\
\text { resources and } \\
\text { absorptive capacity }\end{array}$ & $\begin{array}{l}\text { Survey data from } 42 \\
\text { firms. Quantitative } \\
\text { method using PLS }\end{array}$ & $\begin{array}{l}\text { Process for } \\
\text { exploitation } \\
\text { reputational } \\
\text { resources and } \\
\text { knowledge becomes } \\
\text { an essential element } \\
\text { for firms to adapt to } \\
\text { changes in the } \\
\text { competitive }\end{array}$ \\
\hline
\end{tabular}




\begin{tabular}{|c|c|c|c|c|c|}
\hline & $\begin{array}{lr}\text { resource } & \text { based } \\
\text { approach } & \text { by } \\
\text { Orlando } & \text { and } \\
\text { Alexandra } & (2016\end{array}$ & & & & environment \\
\hline 23 & $\begin{array}{l}\text { How does } \\
\text { corporate social } \\
\text { responsibility } \\
\text { contribute to firm } \\
\text { performance?; } \\
\text { the mediating } \\
\text { role of corporate } \\
\text { reputation } \\
\text { competitive } \\
\text { advantage, } \\
\text { reputation and } \\
\text { customer } \\
\text { satisfaction. } \\
\text { Saeidi et al, } \\
(2015 \text { ) }\end{array}$ & $\begin{array}{l}\text { Journal } \\
\text { of } \\
\text { Business } \\
\text { Research } \\
\text { (Elsevier } \\
\text { ) }\end{array}$ & $\begin{array}{l}\text { Corporate Social } \\
\text { Responsibility } \\
\text { (Independent) firm } \\
\text { performance, } \\
\text { customer } \\
\text { satisfaction } \\
\text { (Dependent), } \\
\text { Competitive } \\
\text { Advantage, and } \\
\text { reputation. } \\
\text { (mediators) }\end{array}$ & $\begin{array}{l}\text { Data was analyzed } \\
\text { using AMOS }\end{array}$ & $\begin{array}{l}\text { The study revealed } \\
\text { that reputation } \\
\text { mediate the } \\
\text { relationship between } \\
\text { corporate social } \\
\text { responsibility and } \\
\text { firm performance. }\end{array}$ \\
\hline \multirow[t]{2}{*}{24} & $\begin{array}{l}\text { Forecasting effect } \\
\text { of creativity on } \\
\text { entrepreneurial } \\
\text { sustainability by } \\
\text { Ogori, Isiakwe, } \\
\text { Ajagbe and Oke } \\
(2015)\end{array}$ & $\begin{array}{l}\text { Institutio } \\
\text { nal based }\end{array}$ & $\begin{array}{l}\text { Creativity and } \\
\text { entrepreneurial } \\
\text { sustainability }\end{array}$ & $\begin{array}{l}288 \quad \text { Qualitative } \\
\text { using SPSS } 22\end{array}$ & $\begin{array}{l}\text { Creativity } \\
\text { adaptation has a } \\
\text { positive impact on } \\
\text { return on investment } \\
\text { and customer base. }\end{array}$ \\
\hline & $\begin{array}{l}\text { Developing } \\
\text { Organizational } \\
\text { Creativity and } \\
\text { Innovation: } \\
\text { Toward a model } \\
\text { of self- } \\
\text { leadership, } \\
\text { employee } \\
\text { creativity, } \\
\text { creativity climate } \\
\text { and Workplace } \\
\text { Innovative } \\
\text { Orientation } \\
\text { By Ghosh } \\
\text { (2015) }\end{array}$ & Emerald & $\begin{array}{lr}\text { Organisational } \\
\text { Creativity } \\
\text { innovation: and } \\
\text { leadership. } & \\
\text { Employee } & \\
\text { creativity } & \\
\text { workplace } & \\
\text { innovative } & \\
\text { orientation } & \end{array}$ & $\begin{array}{l}36 \text { organizational } \\
\text { respondents } \\
\text { comprising of } \\
\text { managers, deputy } \\
\text { managers, and } \\
\text { assistant managers } \\
\text { working in the } \\
\text { research and } \\
\text { development } \\
\text { Self-leadership, } \\
\text { creativity, and } \\
\text { innovation. The tool } \\
\text { use for the study is } \\
\text { structural equation } \\
\text { modelling analysis }\end{array}$ & $\begin{array}{l}\text { Results revealed } \\
\text { the significant } \\
\text { relationships among } \\
\text { self-leadership; } \\
\text { employee creativity, } \\
\text { creativity climate; } \\
\text { and workplace } \\
\text { innovative } \\
\text { orientation }\end{array}$ \\
\hline 25 & $\begin{array}{l}\text { Reputation and } \\
\text { legitimacy. A key } \\
\text { factor for higher } \\
\text { Education. } \\
\text { Institutions } \\
\text { sustained } \\
\text { competitive } \\
\text { advantage. }\end{array}$ & $\begin{array}{l}\text { Journal } \\
\text { of } \\
\text { Business } \\
\text { Research } \\
\text { (Elsevier } \\
\text { ) }\end{array}$ & $\begin{array}{l}\text { Reputation(Indepen } \\
\text { dent) and } \\
\text { Competitive } \\
\text { advantage } \\
\text { (Dependent) }\end{array}$ & \begin{tabular}{lr}
\multicolumn{2}{l}{ Data were collected } \\
using questionnaire \\
with & 509 \\
respondents & from \\
different & public \\
universities in & Spain
\end{tabular} & $\begin{array}{l}\text { Found that } \\
\text { reputation a critical } \\
\text { intangible asset in } \\
\text { order to ensure a } \\
\text { sustainable } \\
\text { competitive } \\
\text { advantage and } \\
\text { therefore guarantee }\end{array}$ \\
\hline
\end{tabular}


Vol. 3 No. 1, February 2022

\begin{tabular}{|c|c|c|c|c|c|}
\hline & Miotto (2020) & & & & $\begin{array}{l}\text { their firm survival } \\
\text { and growth }\end{array}$ \\
\hline 26 & $\begin{array}{l}\text { Investigating the } \\
\text { mediating role of } \\
\text { corporate } \\
\text { reputation on the } \\
\text { relationship } \\
\text { between } \\
\text { corporate social } \\
\text { responsibility and } \\
\text { multiple } \\
\text { stakeholders } \\
\text { outcomes } \\
\text { Arikan, Kantur, } \\
\text { Maiden \& Telci } \\
\text { (2016) }\end{array}$ & $\begin{array}{l}\text { Quality } \\
\text { and } \\
\text { Quantity } \\
\text { (Springer } \\
\text { ) }\end{array}$ & $\begin{array}{l}\text { Corporate Social } \\
\text { Responsibility } \\
\text { (Independent } \\
\text { Variable ) }\end{array}$ & $\begin{array}{ll}9 \text { companies } & \text { were } \\
\text { selected } & \text { from } \\
\text { manufacturing } & \\
\text { industries } & \end{array}$ & $\begin{array}{l}\text { The result showed } \\
\text { that corporate } \\
\text { mediates the } \\
\text { relationship between } \\
\text { CSR and } \\
\text { organizational and } \\
\text { performance } \\
\text { outcomes. }\end{array}$ \\
\hline 27 & $\begin{array}{l}\text { Innovation and } \\
\text { Corporate } \\
\text { reputation and } \\
\text { word of mouth in } \\
\text { the banking } \\
\text { sector in India. } \\
\text { Manohar, Mittal } \\
\text { and Marwash, } \\
(2020)\end{array}$ & $\begin{array}{l}\text { Benchma } \\
\text { rking. An } \\
\text { internatio } \\
\text { nal } \\
\text { Journal } \\
\text { (Emerald } \\
\text { ) }\end{array}$ & $\begin{array}{l}\text { Innovation } \\
\text { (Independent } \\
\text { Variable), Word of } \\
\text { mouth (Dependent) } \\
\text { and Corporate } \\
\text { reputation } \\
\text { (mediator) }\end{array}$ & $\begin{array}{l}\text { The study adopted } \\
\text { an integrated } \\
\text { approach using } \\
\text { qualitative and } \\
\text { quantitative. With } \\
23 \text { participant and } \\
300 \text { respondents. } \\
\text { PLS was used for } \\
\text { data analysis }\end{array}$ & $\begin{array}{l}\text { The study indicates } \\
\text { that corporate } \\
\text { reputation mediates } \\
\text { the relationship } \\
\text { between innovation } \\
\text { and word of mouth }\end{array}$ \\
\hline 28 & $\begin{array}{l}\text { Deep level } \\
\text { diversity and } \\
\text { workgroup } \\
\text { creativity: the } \\
\text { role of creativity } \\
\text { climate by } \\
\text { Tripathi and } \\
\text { Ghosh, (2020) }\end{array}$ & & $\begin{array}{l}\text { Effect of perceived } \\
\text { "self-to-team" } \\
\text { deep-level diversity } \\
\text { on team's creative } \\
\text { output from a } \\
\text { social Identity lens } \\
\text { view }\end{array}$ & $\begin{array}{l}40 \text { employees were } \\
\text { males and } 50 \text { were } \\
\text { females. ANOVA } \\
\text { was used tool for } \\
\text { data analysis }\end{array}$ & $\begin{array}{l}\text { Results indicated } \\
\text { that the deep-level } \\
\text { homogeneous group } \\
\text { perceived higher } \\
\text { team creative output } \\
\text { as compared to the } \\
\text { deep-level } \\
\text { heterogeneous } \\
\text { group. Perceived } \\
\text { team creativity } \\
\text { climate was found } \\
\text { to mediate the effect } \\
\text { of team diversity on } \\
\text { the team's creative } \\
\text { output. Further, it } \\
\text { was observed that } \\
\text { the quality of } \\
\text { perceived creativity } \\
\text { climate (positive } \\
\text { and negative) } \\
\text { moderated the } \\
\text { relationship between } \\
\text { diversity and the } \\
\text { team's creative }\end{array}$ \\
\hline
\end{tabular}




\begin{tabular}{|c|c|c|c|c|c|}
\hline & & & & & output. \\
\hline 29 & $\begin{array}{l}\text { The facet } \\
\text { antecedents and } \\
\text { consequences of } \\
\text { coo petition. An } \\
\text { entrepreneurial } \\
\text { Marketing } \\
\text { perspective. } \\
\text { Crick (2018) }\end{array}$ & $\begin{array}{l}\text { Qualitati } \\
\text { ve } \\
\text { Market } \\
\text { Research } \\
: \quad \text { An } \\
\text { Internatio } \\
\text { nal } \\
\text { Journal. } \\
\text { (Emerald } \\
\text { ) }\end{array}$ & $\begin{array}{l}\text { Entrepreneurial } \\
\text { marketing, Coo } \\
\text { petition, and } \\
\text { Organizational } \\
\text { performance. }\end{array}$ & 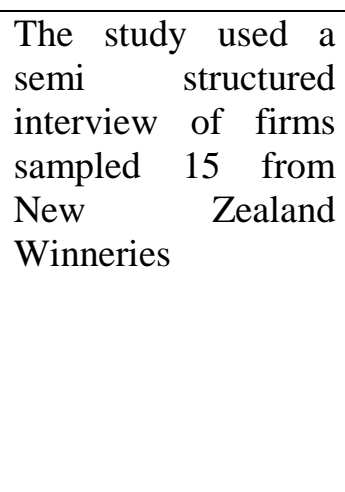 & $\begin{array}{lr}\text { Coo } & \text { petition } \\
\text { comprised } & \text { of } \\
\text { resources and } \\
\text { capability sharing } \\
\text { activities. These } \\
\text { activities are driven } \\
\text { by an industries } \\
\text { wide cooperative } \\
\text { mind set, and } \\
\text { entrepreneurial } \\
\text { marketing }\end{array}$ \\
\hline 30 & $\begin{array}{l}\text { Relating word-of- } \\
\text { mouth to } \\
\text { corporate } \\
\text { reputation by } \\
\text { Williams, Buttle } \\
\text { and Biggemann } \\
(2012)\end{array}$ & $\begin{array}{l}\text { Institutio } \\
\text { nal based }\end{array}$ & $\begin{array}{l}\text { Word-of-mouth } \\
\text { and corporate } \\
\text { reputation }\end{array}$ & $\begin{array}{l}\text { Three organisations } \\
\text { Literature review }\end{array}$ & $\begin{array}{l}\text { Customers } \\
\text { dissatisfaction and } \\
\text { negative word of } \\
\text { mouth are thought } \\
\text { to have strong down } \\
\text { side consequence } \\
\text { for corporate } \\
\text { reputation }\end{array}$ \\
\hline 31 & $\begin{array}{l}\text { The Effect of } \\
\text { Entrepreneurial } \\
\text { Marketing on } \\
\text { Outcome Goals } \\
\text { in SMEs BY } \\
\text { Becherer, Helms } \\
\text { and McDonald }\end{array}$ & $\begin{array}{l}\text { Institutio } \\
\text { nal }\end{array}$ & $\begin{array}{l}\text { Entrepreneurial } \\
\text { Marketing on } \\
\text { Outcome Goals in } \\
\text { SMEs }\end{array}$ & $\begin{array}{l}1,800 \\
\text { owners/operators of } \\
\text { small to medium- } \\
\text { sized businesses } \\
\text { (SMEs). } \\
\text { Stepwise regression } \\
\text { was used to } \\
\text { analyzed the data }\end{array}$ & $\begin{array}{l}\text { Results revealed } \\
\text { entrepreneurial } \\
\text { marketing impacts } \\
\text { outcome variables, } \\
\text { particularly value } \\
\text { creation. }\end{array}$ \\
\hline 32 & $\begin{array}{l}\text { Culture and age } \\
\text { as moderators in } \\
\text { the corporate } \\
\text { reputation and } \\
\text { loyalty } \\
\text { relationship } \\
\text { Bartikouski et al, } \\
(2011)\end{array}$ & $\begin{array}{l}\text { Journal } \\
\text { of } \\
\text { Business } \\
\text { Research } \\
\text { (Elsevier } \\
\text { ) }\end{array}$ & $\begin{array}{l}\text { Corporate } \\
\text { Reputation( } \\
\text { Independent } \\
\text { variable), loyalty } \\
\text { (Dependent } \\
\text { variable) }\end{array}$ & $\begin{array}{l}\text { Convenient } \\
\text { sampling technique, } \\
\text { questionnaires were } \\
\text { adopted from } \\
\text { previous study } \\
\text { studies and were } \\
\text { measured on } 5 \\
\text { point- Likert scale. }\end{array}$ & $\begin{array}{l}\text { Results suggest that } \\
\text { consumer corporate } \\
\text { reputation have a } \\
\text { positive effect on } \\
\text { affective and } \\
\text { intentional loyalty }\end{array}$ \\
\hline 33 & $\begin{array}{l}\text { Relationship } \\
\text { between market } \\
\text { orientation, brand } \\
\text { orientation and } \\
\text { perceived } \\
\text { benefits in the } \\
\text { non-profit sector: } \\
\text { a customer } \\
\text { perceived } \\
\text { paradigm by } \\
\text { Mulyanegara } \\
\text { (2011 }\end{array}$ & $\begin{array}{l}\text { Taylor } \\
\text { and } \\
\text { Francis }\end{array}$ & $\begin{array}{l}\text { Market orientation, } \\
\text { brand } \\
\text { orientation and } \\
\text { perceived benefits }\end{array}$ & $\begin{array}{l}13 \text { church } \\
\text { organizations. } \\
\text { Quantitative using } \\
\text { PLS }\end{array}$ & $\begin{array}{l}\text { Findings reveal that } \\
\text { market orientation is } \\
\text { significantly } \\
\text { associated with both } \\
\text { perceived brand } \\
\text { orientation and } \\
\text { perceived benefit }\end{array}$ \\
\hline
\end{tabular}




\subsection{Proposed Measures}

Entrepreneurial Marketing: Though different versions of entrepreneurial marketing measures have evolved over time (Becherer et al 2012; Fiore, et al, 2013; Jones \& Rowley 2011). We found the scale development by Fiore et al, (2013) robust with Cronbach Alpha 0. 8. It is a 12 items measurement for entrepreneurial marketing which has been used extensively in studies relating to small scale enterprises. It was measured on a 5 point Likert typed scale.

Corporate Reputation: A number of scales have been developed to measure corporate reputation (Fombrum, Gardberg \& Saver, 2000, Helm, 2015; Feldman, Behamonde \& Bellido, 2013). However, our study found that the scale development by Fombrum et al, (2000), reputation quotient, remains the most popular measure (Shamma, 2012) because it was one of the first measures for reputation, other measurement scales were developed from the corporate reputation quotient. Similarly, Wartick (2012) claims that the reputation quotient is a good measure, that makes it applicable to most stakeholder groups and many cultural contexts.

Corporate Creativity: In measuring corporate creativity a number of scales have been developed and validated (Tierney, Farmer \& Graen, 1999). However, we adapt the scale developed by Tierney et al, (1999) using a sample of 5 items with a Cronbach, Alpha 0.88 for 5 items.

Competitive Advantage: A number of measures have been developed to measure competitive advantage (Chen, Lin \& Chang 2009; Gilley, Greer \& Rasheed, 2004; Argote \& Ingram, 2000). We found Chen et al's, (2009) scale robust with Cronbach Alpha of 0.85. It is measured on 5 point Likert typed scale.

\section{Result and Discussion}

In an attempt to understand the usage of entrepreneurial marketing practices in business environment, this study proposed a parsimonious model of the entrepreneurial marketing, taking into cognizance of business environment in which firms operate. This study leverages on dynamic capability theory (Teece, et al, 1997), image theory (Beach et al, 1998) as the theoretical foundation, while $\mathrm{CR}, \mathrm{CC}$, and $\mathrm{CA}$ are proposed as the mechanism boundary condition and consequence of EM respectively. The proposed model provides an all summarizing approach that centers on the entirety of stakeholders' interactions in the business environment. This would be beneficial to future research regarding the consequences of entrepreneurial marketing in the future business environment which recent global trend seems to be uncertain about.

Theoretically, incorporating corporate reputation and corporate creativity into the model, entrepreneurial marketing model has underscored the importance of firm reputation and resources capability in the entrepreneurial marketing competitive advantage link. Understanding the entrepreneur's capabilities and firm's reputation and good marketing practices would increase likely corporate creativity in such manner that firms marketing behavior would enhance and clarify the multifaceted characteristic of entrepreneurial marketing as it relates to firm's outcomes. 
The study also made contributions to the field of strategic marketing, especially in the context of entrepreneurial marketing. Poor performance of small firms poses serious challenge for entrepreneurs; this places firms at the disadvantaged side (Sadiku-Dushi et al, 2019). Thus, understanding the consequences of the phenomenon especially in this difficult period where most businesses are facing the scourge of Covid-19 pandemic coupled with already existing challenges is critical. Worse incidences of performance and collapse of these small firms would increasingly be reported if survival factors critical to firms' success are ignored. A model to comprehend this occurrence particularly from the viewpoint of small firms is germane.

\section{Conclusion}

The main limitation of this study is that the model of entrepreneurial marketing developed in this study is conclusion based on the fact obtained from the current debates in literature. Therefore, there is need to empirically test the model using collected data with the help of the suggested measures. We recommend that researchers validate this model across a number different contexts and industries. Secondly, inclusion of articles in the review is not scientifically determined but based on the authors' discretion and limitation to most data bases. It is possible some high impact journals are unavoidably inaccessible and would have influenced the perspectives of the authors on the consequences of EM as proposed in this study. We recognize that inclusion of more findings from different context in the future reviews, will result in capturing and highlighting critical constructs that explain the consequences of EM as it relates to diverse cultures and industries. Fourthly, Organizational climate (Shanker, Bhanugopan, Van der Heijden, \& Farrell, 2017) has been found to impact on organizational outcome positively. We expect that where solidarity and shared vision is common among members of the organization, creativity will further be enhanced, thus the role of organizational climate that supports this attitude is worth exploring.

\section{References}

Abdullahi, A., Muhammad, M., Syed, A., \& Ghazali, B.N. (2017). Effect of entrepreneurial Orientation on consumer engagement and performance of manufacturing SMEs. Management Research Review 4 (1), 133-14.

Abratt, R., \& Kleyn, N. (2012). Corporate identify, corporate branding and corporate reputation. Reconciliation and Integration. European Journal of Marketing, 46(7\8), 1048- 1063.

Akpi, J. S., Vem, L. J., \& Eshue, P. O. (2020). Does corporate reputation matter in the relationship between organizational cultural intelligence and customer loyalty among SMEs in Nigeria? Journal of Research in Emerging Markets, 2(2), 73-88.

Aksak, E. O., Ferguson, M. A., \& Duman, S. A. (2016). Corporate social responsibility and CSR fit as predictors of corporate reputation: A global perspective. Public Relations Review, 42(1), 79-81. 
Al- Najjar, F.J. (2016). Social responsibility and its impact on competitive advantage an applied study on Telecommunication Companies. International Journal of Business and Social Sciences, 7 (2), 114-125.

Al-Mamun, A., Mohiuddin, M., Fazal, S.A., \& Ahmad, G.B. (2018), Effect of entrepreneurial and market orientation on consumer engagement and performance of manufacturing SMEs", Management Research Review, 41(1), 133-147,

Anderson, N., Potočnik, K., \& Zhou, J. (2014). Innovation and creativity in organizations. A state-of-the-science review, prospective commentary, and guiding framework. Journal of Management, 40(5), 1297-1333.

Annan, J., \& Adeola, O. (2017). Does organization creativity and always drive market performance. Psychology and Marketing. $\quad 34(11), 1004-105$

Argote, L., \& Ingram, P. (2000). Knowledge transfers a basis for competitive advantage in firms. Organizational Human Decision Process, 82(1), 150 - 69.

Arikan, E., Kantur, D., Maiden, C., \& Telci, E.E. (2016). Investigating the mediating role of corporate reputation on the relationship between corporate social responsibility and multiple stakeholders outcomes. Quality and Quantity. 50(1), 129- 149.

Bachmann, J.H., Ohlies, I \& Flatten, T. (2021). Effects of entrepreneurial marketing on new ventures exploitative and innovation. The moderating role of competitive intensity and firm size. Industrial Marketing Management, 87, (2020), 102499

Barney, J.B. (1991). Firm resources and sustained competitive advantage. Journal Management 17(1), $99-120$.

Baron, R.M., \& Kenny, D.A. (1986). The moderator- mediator variable distinction in social psychological research. Conceptualstrategic and statistical consideration. Journal of Personnel Social Psychology, 51, 1173- 1182.

Bartikowski, B., Walsh, G., \& Beatty, S. E. (2011). Culture and age as moderators in the corporate reputation and loyalty relationship. Journal of Business Research, 64(9), 966-972.

Beach, L.R., \& Mitchell, T.R. (1998). The basics of image theory, in Beach L.R. (ed) image theory, theoretical and empirica foundations. New Jersey: Lawrence Erlbaum, Hillsdale

Becherer, R., Helms, M., \& McDonalds, J. (2012). The effect of entrepreneurial marketing on outcome goals in SMEs. New England Journal of Entrepreneurship. 15, 7-12.

Bjerke, B., \& Hultman, C.M. (2002), Entrepreneurial marketing: The growth of small firms economic Era, Edward Elgar Publishing Limited, Aldershot.

Bratic, D. (2011), Achieving competitive advantage by SCM. IBIMA Business Review, 20 (2), $13-19$.

Bruna, M.G., \& Nicolo, D. (2020). Corporate reputation and social sustainability in the early stages of start - ups. A theoretical model to match stakeholders expectations through corporate social commitment. Finance Research Letters, 35(2020), 101508 
Buccieri, D., Javalgi, R.G., \& Gross, A. (2021). Innovation and differentiation of emerging market in international new ventures the role of entrepreneurial marketing. Journal of Strategic Marketing (2021), 1- 29

Carreras, C., Alloza, A., \& Carreras, A., (2013). Corporate reputation, London: LID Publishing.

Chen, Y.S., Liu, M.J.J., \& Chang, C.H. (2009). The positive effect of relationship, learning and absorptive capacity on innovation performance and competitive advantage in

Collinson, E., \& Shaw, E. (2001). Entrepreneurial marketing a historical perspective on development and practice. ManagementDecision, 39(9), 761-766.

Crick, J.M. (2018). The facet antecedents and consequences of coo petition. An entrepreneurial marketing perspective. Qualitative Market Research: An International Journal 21(2), 253- 272.

Csikszentmihelyi, M., \& Sawyer, K. (2014). Shifting the focus firm individual to organizational creativity. The Systems Model of Creativity, 2014, 67-71

Darvishmontevali, M., Altinay, L., \& Kaseoglu, M.A.(2020). The linking between environmental uncertainty and organizational agility and organizational creativity in the hotel industry. International Journal of Hospitality Management, 87(2020), 102499

De Vasconcellos, S. L., Garrido, I. L., \& Parente, R. C. (2019). Organizational creativity as a crucial resource for building international business competence. International Business Review, 28(3), 438-449.

Diab, S.M. (2014). Using the competitive dimensions to achieve advantage. A study on Jordanian private hospitals. International Journal of Academic Research in Business and Social Sciences 4(9), 138 - 150

Dixit, S., Singh, S., Dhir, S., \& Dhir, S. (2021). Antecedents of strategic thinking and its impact on competitive advantage. Journal of Indian Business Research (in Press)

D'Souza, C., Taghian, M., \& Sullivan-Mort, G. (2013). Environmentally motivated actions influencing perceptions of environmental corporate reputation. Journal of Strategic Marketing, 21(6), 541-555.

Eggers, F., Niemand, T., Kraus, S., \& Breier, M. (2020). Developing a scale for entrepreneurial marketing: Revealing its inner frame and prediction of performance. Journal of Business Research, 113, 72-82.

.Feldman, P.M., Behamonde, C. A., \& Bellido, J.V. (2013). New Approach for Marketing Corporate Reputation. Revista de- Administracao de-Empresas 54(1), 53-66

Ferreira, C.C., Ferguson, S.L., \& Pitt, L.F. (2019). Entrepreneurial marketing and hybrid Entrepreneurship; the case of Reid Bamboo Rods. Journal of Marketing of Management, 35(9), $867-885$. 
Fiore, A.M., Niehm, L.S., Hurst, J.L., Son, J., \& Sadachar, A. (2013), Entrepreneurial marketing: scale validation with entrepreneurial marketing, scale validation with small independent owned businesses firm. Journal of Marketing Development and Competitiveness, 7(4), 63-86.

Fombrun, C. (1996). Reputation: Realizing value from corporate image, Boston: Harvard Business School Press

Fombrun, C.J., Guadberg, N. A., \& Saver, J.M. (2000). The reputation quotient a multiple stakeholder measure of corporate reputation. Journal of Brand Management. 7(4), 240- 252

Gaddefors, J. \& Anderson, A.R. (2008), Market creation: the epitome of entrepreneurial marketing practices, Journal of Research in Marketing and Entrepreneurship, 10(1), 19-39.

Ghosh, K. (2015). Developing organizational creativity and innovation. Management Research Review, 38(11), 1126 - 1148

Gilley, K.M., Geer, C.R., \& Rasheed, A, A. (2000). Human resource outsourcing and organizational performance in manufacturing firms. Journal of Business Research $57,232-240$.

Gilmore, A., McAuley, A., Gallagher, D., \& Carson, D. (2013). Entrepreneurship and interface research - A synopsis and evaluation. In Z. Sethna, R. Jones, \& P. Harrigan Eds.), Entrepreneurial marketing global perspectives (pp. 321).Warrington:Emerald Group Publishing Limited.

Grissemann, U., Plank, A., \& Brunner- Sperdin, A.(2013). Enhancing business performance of hotels. The role of innovation and customer orientation. International Journal of Hospitality Management, 33 (2013), 347- 356

Gontur, S., Davireng, M., \& Gadi, P.D. (2016). Creativity and innovation as a strategy for enhancing entrepreneurship development. Journal of Teacher Perspective 10(2), $1-16$

Hacioglu, G., Eren, S.S., Eren, M.S., \& Celikkan, H. (2012). The effect on of entrepreneurial marketing on firm is innovative performance in Turkish SMEs. Social and Behavioural Science, 58, 871-876.

Harrigan, P., Ramsey, I., \& Ibbotson, P. (2012). Entrepreneurial marketing in SMEs: the key capabilities of e - CRM. Journal of Research in Marketing and Entrepreneurship, 14(1), $40-64$.

Hills, G.E., \& Hultman, C.M. (2011). Academic roots the past and present of entrepreneurial marketing. Journal of Small and Business and Entrepreneurial. 4(1), 1-10.

Hills, G.E., Hultman, C.M., \& Miles, P.M. (2008). The evolution and development entrepreneurial marketing, Journal of Small

Business Management, 46 (1), 99112. 
Hills, G.E., Hultman, C.E., Kraus, S., \& Schulte, R. (2010), History, theory and evidence of entrepreneurial marketing: an overview, International Journal of Entrepreneurship and Innovation Management, 11(1), 3-18.

Jansson, J., Nilsson, J., Modig, F. \& Hed, V. (2015). Commitment to sustainability in small and medium sized enterprises. The influence of strategic orientations and management values. Business Strategy and the Environment, 1- 16.

Jayawarna, D., Jones, O., Lam, W. \& Phua, S, (2014). The performance of entrepreneurial ventures: Examining the role of marketing practices, Journal of Small Business and Enterprise Development, 21(4), 565 - 587.

Ji, Y. G., Li, C., North, M., \& Liu, J. (2017). Staking reputation on stakeholders: How does stakeholders' face book engagement help or ruin a company's reputation? Public Relations Review, 43(1), 201-210.

Jones, R. \& Rowley, J. (2011), Entrepreneurial marketing in small businesses: a conceptual exploration. International Small Business Journal, 29(1), 25-36.

Kamasak, R. (2017). The contribution of tangible resources, and capabilities to a firm'sprofitability and market performance. European Journal of Management and Economics. 26 (2), 252- 275.

Kanyabi, Y., \& Devi, S. (2012). The impact of advisory services on Iranian SME performance: An empirical investigation of the role of professional accountants. African Journal Business Management, 43(2), 61-72

Kathiravan, C., Bhagevatham, P.V., Palanisamy, V., \& Rajasekar, A. (2019). Influence of entrepreneurial creativity on competitive advantage in automobile engineering and technologies industries. International Journal of Advanced Science and Technology 27(1), 166-172

Kraus, S., Harms, R. \& Fink, M. (2010), Entrepreneurial marketing: moving beyond marketing in new ventures, International Journal and Innovation Management, 11(1), 19-34.

of Entrepreneurship

Koch, J., Wenzel, M., Senf, N. N., \& Maibier, C. (2018). Organizational creativity as an attributional process: The case of haute cuisine. Organization Studies, 39(23), 251-270.

Kurgun, H., Bagiran, D., Ozeren, E., \& Maral, B. (2011). Entrepreneurial marketing-The interface between marketing and entrepreneurship: A qualitative research on boutique hotels. European Journal of Social Sciences, 26, (3), 340-357

Li, J.J., \& Zhou, K.Z. (2010). How foreign firms achieve competitive advantage in the Chinese emerging economy. Management and market orientation. Journal of Business Research 63, 856-862.

Li, S., Nathan, R., Nathan, T.S.R., \& Rao, S. (2006). Impact of supply chain management practices on competitive advantage organizational performance. Omega, 34(2), 107-124. 
Mahrous, A., Genedy, M.A., \& Kalliny, M. (2020). The impact of characteristics of intra organizational environment on entrepreneurial marketing intensity and performance in Egypt. Journal of Entrepreneurship in Emerging Economies. 12(5), 621- 642.

Maliszewska, M., Mattoo, A. \& Mensbrugghe, V.D. (2020). The potential impact of COVID 19 on GDP and trade: A preliminary assessment, Policy Research Working Paper, no Wps 9211; COVID 19. Washington D.C. World Bank Group

Massey, J.E. (2011). Organizational image management in M. Daes, M. Brown (Eds). The prequisite of organizational commission. New York: McGrawn Hill

Manohar, S., Mittal, A., \& Maroush, S. (2020). Service innovation, corporate reputation and word of mouth in the banking sector. A test on multi group moderated effect. Benchmarking. An International Journal, 27(1), 406- 429

Masson, A.M. (2014). The impact of media firms and treatment responsibility within the situational crisis communication theory frame. Corporate Reputation Review 17(1), 78- 90.

Mihalic, T., \& Buhalis, D. (2013). ICT as new competitive advantage factor case of small transitional hotel sector. Economic \& Business Review. 15(1), 33- 56.

Miles, M.P., Lewis, G.K., Hall, P., Morrish, S.C., Gilmore, A., \& Kasouf, C.J. (2016). The influence of entrepreneurial marketing process and entrepreneurial self efficacy on community vulnerability, risk and resilience. Strategic Marketing, 24(1), 34-46.

Miotto, G., Del- Castillo- Fato, C., \& Blanco- Gonzalez, A. (2020). Reputation and legitimacy; key factors for higher, institutions sustained competitive advantage. Journal of Business Research (in press)

Morris, M.H., Schindehutte, M., \& LaForge, R.W. (2002), Entrepreneurial marketing: a construct for integrating entrepreneurship and marketing perspectives, Journal of Marketing Theory and Practice, 10(4), 1-19.

Morrish, S.C., \& Jones, R. (2020). Post disaster business recovery. An entrepreneurial marketing perspectives. Journal of Business

Research, 113(2020), 83-92

Morrish, S.C., Miles, M.P. \& Deacon, J.H. (2010). Entrepreneurial marketing; Acknowledging the entrepreneurs and customer-centric. Journal of Strategic Marketing 18(4), 303-316

Mugambi, E. N. \& Karugu, W. N. (2017). Effect of entrepreneurial marketing on performance of real estate enterprises: a case of optiven limited in Nairobi, Kenya International Academic Journal of Innovation, Leadership and Entrepreneurship, 2(1), $26-45$.

Mulyanegocra, R.C. (2011). The relationship between market orientation, brand orientation and received benefits in the non-profit. Journal of Strategic Marketing. 19 (5), 429441.

Njeru, W.G., \& Kibera, F.N. (2016). Marketing practices, market orientation and performance of tour firms in Kenya. A mediated approach. DBA Africa Journal of Management 6(4), 33- 49. 
Okocha, E.B., Otika, U.S. \& Osuagwu, B.O. (2019). Relationship between corporate image and competitive advantage in mobile telecommunication industry in Nigeria. European Journal of Innovative Business Management 3, 1 - 9.

.Olannye, A.P., \& Eromafuru, E. (2016). The dimensions of entrepreneurial marketing on the performance of fast Food restaurant. Asaba, Delta state Nigeria. Journal of Emerging Trends in Economic and Management Science.7 (3), 137-146.

Ogbari, M.I., Isaiavwe, D.T., Ajagbe, M. A. \& Oke, A. (2015). Forecasting effect of creativity on entrepreneurial sustainability. International Journal of Academic Research in Business and Social Sciences. 5(17), 123 - 139.

Omura, G. S., Calantone, R. J.\& Schmidt, J. B. (1993). Entrepreneurism as a market satisfying mechanism in a free market system, Hills and Mohan-Neill, (Eds). Scholarly justification, research at the marketing/entrepreneurship Interface, in Hills,G. E. (Ed.). Chicago: University of Illinois at Chicago, 161-171

Orlando, L.R., \& Alexandra, F. (2018). Assessing the relationship between entrepreneurial orientation a reputational essential and absorptive capability. A Resources Based Approach. 26 (1) 30-37.

Ozdora- Akak, E., Ferguson, M.A., \& Atakan, Duman, S. (2016). Corporate social responsibility and CSR fit as predictors of corporate reputation. A global perspective. Public Relations Review, 42(1), 79- 81

Ozkan, P. Suer, S., Keser, I.K., \& Kocakoc, I.D. (2019). The effect of service quality and customer satisfaction on customer loyalty. The mediating role of perceived value of services, corporate image and reputation. International Journal of Bank Marketing, 38(2), 384- 405

Park, E (2019). Corporate social responsibility as a determinant of corporate reputation in the airline industry. Journal of Retailing and Consumer Services, 47(2019), 215- 221

Park, H.Y., Cho, H., Park, S., \& Shin, G.C. (2019). Application of white- heachen creativity to corporate creativity a fire as creativity model. Advance Social Sciences and Humanities, 2019, 1 -33.

Peng, D., Schroeder, R. G., \& Shah, R. (2011). Competitive priorities, plant improvement and Innovation capabilities and operational performance. A test of two forms of fit. International Journal of Operations and Production Management, 31(5), 484 - 510.

Peterson, M. (2020). Modeling country entrepreneurial activity to inform entrepreneurialmarketing research. Journal of Business $\quad$ Research, 113, 105-116.

Pham, H.S., \& Tran, H.T. (2020). Corporate social responsibility disclosure and firm performance. The mediating role of corporate reputation and moderating role of CEO integrity. Journal of Business Research, 120(2020), 127- 136

Quintana-García, C., Benavides-Chicón, C. G., \& Marchante-Lara, M. (2020). Does a green supply chain improve corporate reputation? Empirical evidence from European manufacturing sectors. Industrial Marketing Management. (in press). 
Rezvani, M., \& Fathollabzadeh, Z. (2020). The impact of entrepreneurial marketing on innovative marketing performance in small and medium companies. Journal of Strategic Marketing, 28(2), 136- 148

Rollins, B., Anitsal, I., \& Anitsal, M. M. (2014). Viral marketing techniques and implementation. Entrepreneurial Executive. 19, 1 -

Rothaermal, F.T. (2013). Strategic management. Concepts and cases. New York: McGraw Hill

Rua, O. L., \& França, A. (2018). Assessing the relationship between Entrepreneurial Orientation, Reputational Resources and Absorptive capability: A resource-based approach. Periodica Polytechnica Social and Management Sciences, 26(1), 30-37.

Sadiku- Dushi, S.N., Dana, L.P., \& Ramadani, V. (2019). Entrepreneurial marketing dimensions and SMEs performance. Journal of Business Research, 100 (2019), 8699.

Saeidi, S.P., Sofian, S., Saeidi, P., Saeidi, S.P., \& Saeidi, S.A. (2015). How does corporate social responsibility contribute to firm performance? The mediating role of competitive advantage, reputation and customer satisfaction. Journal of Business Research, 68(2), 341-350.

Shamma, H.M. (2012). Toward a comprehensive understanding of corporate, corporate reputation, concept, measurement and implications. International Journal Business and Management. 7 (16), 150- 169.

Shanker, R., Bhanugopan, R., van der Heijden, B. I., \& Farrell, M. (2017). Organizational climate for innovation and organizational performance: The mediating effect of innovative work behavior. Journal of Vocational Behavior, 100, 67-77.

.Sigalas, C. Pekka-Economou, V., \& Geogopolous, N.B. (2013) Developing a measure of competitive advantage. Journal of Strategy and Management, 6 (4), 320-342.

Sole, M. (2013), Entrepreneurial marketing: conceptual exploration and link to performance. Journal of Research in Marketing and Entrepreneurship, 15(1), 23-38

Sutapa, S., Mulyana, M., \&amp; Wasitowati, W. (2017). The role of market orientation, creativity and innovation in creating competitive advantages and creative industry performance. JDM (Jurnal Dinamika Manajemen), 8(2), 152-166.

Teece, D.J., Pisano, G., \& Shuen, A. (1997). Dynamic capabilities and strategic management. Strategic Management Journal. 18 (7), 509- 553.

Tierney, P., Farmer, S.M., \& Graen, G.B.(1999). An examination of leadership and employee creativity. The relevance of traits and relationships. Personnel Psychology. 52 (3),591- 620 .

Tripathi, V., \& Ghosh, V. (2020). Deep - level diversity and work group creativity. The role of creativity diversity climate. Journal of India Business Research, 12(4), 605- 624 
Van- der Merweir, A.W.A.J., \& Puth, G. (2014). Towards a conceptual model of the relationship between corporate reputation. Corporate Reputation Review, 17 (2), 138 $-156$

Wartick, L.S. (2002). Measuring corporate reputation, definition and data. Business and Society. 41 (4). 371-392

Waereaas, A. (2015). Making a difference strategic position on municipal reputation building. Local Studies, 41(2), 280- 300.

Whalen, P., Uslay, C., Pascal, V., Omura, G., McAuley, A., Kasouf, C., Jones, R., Hultman, C., Hills, G., Hansen, G., Gilmore, A., Giglierano, J., Eggers, F. \& Deacon, J. (2016), Anatomy of competitive advantage: towards a contingency theory of entrepreneurial marketing, Journal of Strategic Marketing, 24(1), 5-19

Williams, M., Buttle, F., \& Biggerman, S. (2012). Relating word of mouth to corporate reputation. Public Communication Review. 2

(2), 3-17.

Woodman, R. W., Sawyer, J. E., \& Griffin, R. W. (1993). Toward a theory of organizational creativity. Academy of Management Review, 18(2), 293-321.

Younesi, M., \& Esmaeili, M. (2021). A company's reputation. Influencing customer demand. 115- 134. Taylor and Francis

Zameer, H., Wang, Y., \& Yasmeen, H. ( 2020). Reinforcing green competitive advantage through green production, creativity and brand image.Implications for cleaner production in China. Journal of Cleaner Production. 247, 2020, 119119

Zeebaree, M.R.Y \& Siron, R.B. (2017). The impact of entrepreneurial orientation on competitive advantage moderated by financing support in SMEs. International Review of Management and Marketing. 7(1), 43-52

\section{Copyrights}

Copyright for this article is retained by the author(s), with first publication rights granted to the journal.

This is an open-access article distributed under the terms and conditions of the Creative Commons Attribution license (http://creativecommons.org/licenses/by/4.0/) 